Klemen Kocjančič

\title{
Ne samo vez z Bogom: razvoj vloge in dolžnosti vojaških duhovnikov skozi zgodovino ${ }^{1}$ Not Only a Connection with God: Historical Deve-
lopment of Roles and Duties of Military Chaplains
}

Povžetek: Avtor v članku preučuje različne naloge in dolžnosti, ki jih opravljajo vojaški duhovniki v sklopu duhovne oskrbe pripadnikov oboroženih sil. Zgodovinski zgledi kažejo, da je bil razvoj duhovne oskrbe v oboroženih silah v prvih dveh tisočletjih zelo počasen, a je $v$ zadnjih nekaj desetletjih presegel stare okvire delovanja vojaških duhovnikov. Ti duhovniki tako ne le zagotavljajo pastoralno oskrbo, ampak so postali svetovalci, terapevti itd., ki pomagajo ne samo vojaškemu osebju, ampak tudi njihovim družinskim članom, sodelujejo z nevladnimi organizacijami in imajo lahko tudi neposredni vpliv na razvoj vojaško-političnih dogodkov. Delo vojaških duhovnikov sedaj presega klasični teološko-religiološki okvir, posega namreč tudi na področja medicine, psihologije, kulturologinje zakonsko-družinske terapije in sorodnih ved.

Ključne besede: vojaški duhovnik, duhovna oskrba, religija, oborožene sile, vojaške družine, veterani

Abstract: In the article, the author examines military chaplains' different duties and responsibilities while providing spiritual care for military personnel. Historical examples show that while the development of spiritual care in the military (armed forces) in the first 2,000 years was slow, spiritual care surpassed the old framework of military chaplains in recent decades. Currently, military chaplains provide spiritual care and become counsellors, therapists, and so forth, not only for the military personnel but also for their family members. At the same time, they cooperate with non-governmental organizations and significantly impact military-political events. Military chaplains' duties now exceed classical theological-religious activities, as they also cover areas of medicine, psychology, cultural studies, marriage and family therapy, and other related fields.

1 Raziskovalni projekt št. J5-1786 (B): „Vojaško specifični dejavniki tveganja za dobrobit in zdravje vojaških družin" je sofinancirala Javna agencija za raziskovalno dejavnost Republike Slovenije iz državnega proračuna. 
Keywords: Military Chaplain, Spiritual Care, Religion, Armed Forces, Military Families, Veterans

\section{Uvod}

Vojske oziroma oborožene sile se že od nekdaj navzoče v človeški zgodovini, enako kakor je tudi religija. Presek teh dveh družbenih struktur pomenijo vojaški duhovniki (tudi vojaški kurati, kaplani itd.), ki delujejo znotraj oboroženih sil in zagotavljajo duhovno oskrbo vojaških oseb. Ta oskrba pomeni "pravico vojaškega osebja do izpovedovanja vere« oziroma »duhovno oskrbo vseh, ki jih zadeva vojska tako v času miru, kot v času vojaških vaj ali vojne, in tudi v multinacionalnih enotah: vojakov na rednem služenju; poklicnih vojakov, podčastnikov in častnikov; posameznikov, ki začasno po pogodbi delujejo v vojski; in civilnega osebja, ki deluje v vojski.« (Plut 2002, 16)

Princip sodobnega organiziranega vojaškega duhovništva izhaja iz katoliške Cerkve, ko je koncil v Ratisboni leta 742 potrdil, da imajo lahko vojaški voditelji pri sebi škofa in ali duhovnike, ki so imeli nalogo, „da poslušajo spovedi mož in jim odrejati primerno pokoro«. V naslednjih stoletjih so se dolžnosti vojaških duhovnikov razširile (Johnston 2009, 25-26; Liuski in Ubani 2020, 2).

Šele v drugi polovici 19. stoletja so na mednarodni ravni priznali nekatere pravice vojaških kaplanov in jim zagotovili podobno zaščito kakor vojaškozdravstvenemu osebju, prek uveljavitve ženevske konvencije iz leta 1864, poznejših dopolnil in drugih mednarodnih pravnih aktov (Lunze 2004, 70).

Ta članek bo na podlagi zgodovinskih izkušenj analiziral različne vloge in naloge, ki so jih izvajali oziroma jih še izvajajo vojaški duhovniki, da bi ugotovili, kam lahko vodi nadaljnji razvoj njihovih zadolžitev. Hkrati bo članek dopolnil zelo skromno bero znanstvenoraziskovalnih del na področju duhovne oskrbe oboroženih sil; poleg dveh doktorskih disertacij (Plut 2001; Šimac 2013) in na njih temelječih publikacij (Plut 2002; Šimac 2014) ter dveh zbornikov vojaškega vikariata (Pregelj, Plut in Petelinšek 2005; Plut, Mesarić in Sadar 2010) obstajajo tudi splošni članki o duhovni oskrbi (Čepar 2000, 2010; Mesarič 2012; Plut in Mesarič 2003; Pregelj 2017; Kladnik 2017), pa tudi članki o posameznih slovenskih vojaških duhovnikih (Ratej 2014; Šimac 2020a, 2020b).

\section{Vez z Bogom prek svete daritve}

Že v antičnih časih so z vzpostavitvijo organizirane religije svečeniki, šamani oziroma duhovniki spremljali vojščake, ki so odhajali v boj s sosednjimi plemeni, še posebno če so jih vodili vladarji. O tem govori že Stara zaveza:

»Kadar greš v boj proti sovražnikom in zagledaš konje in bojne vozove in ljudstvo, številnejše od tebe, se jih ne boj! Kajti s teboj bo GOSPOD, tvoj 
Bog, ki te je pripeljal iz egiptovske dežele. Ko boste blizu boja, naj nastopi duhovnik, govori naj ljudstvu in mu reče: sPoslušaj, Izrael! Danes ste pred bojem s sovražniki. Naj vam ne upade srce; ne bojte se in ne plašite se in naj vas ne bo strah pred njimi! Kajti GOSPOD, vaš Bog, hodi z vami, da se bo bojeval za vas z vašimi sovražniki in vam dal zmago.ı « (5 Mz 20,1-4).

Povezava med svečeniki in vojaškimi poveljniki je bila zelo močna v starem Egiptu, kjer je v predptolomejskem Egiptu okoli četrtina častnikov imela (predhodne) svečeniške obveznosti, medtem ko je ta odstotek še narasel pod Ptolomejci - na 38 \% (Fischer-Bovet 2014, 304).

Vloga duhovnikov znotraj vojske se je začela institucionalizirati z vzpostavitvijo stalnih vojska; prva takšna zabeležena vojska sega v čas vladavine asirskega kralja Tiglath-Pileserja III., ki je vladal v 8. stoletju pr. Kr. in se je tudi boril proti antičnemu Izraelu (Schwartzwald 2014, 24). V antični Evropi so Grki vzpostavili prve stalne vojske mestnih držav, pri tem pa je bila religija oziroma vera pomembna tudi pri izvajanju vojaških nalog. Še pred začetkom vojne so za mnenje prosili preroka, nato je moral kralj s pomočjo svečenikov opraviti daritev za pridobitev božjega blagoslova. Daritev je sledila pred odhodom vojske na bojišče, pred prečkanjem vsake reke, pred vsako bitko in po vsaki bitki (Naiden 2019, 10).

Podobno so v starorimski vojski imeli duhovnike, ki so spremljali vojake na bojišče, pa tudi z njimi živeli v vojaških postojankah, mestih itd. Prvi zapiski o vojaških duhovnikih v rimski vojski segajo v drugo polovico 5. stoletja. Tako je rimski general Evzebij ob nedeljah dovolil krščanskim vojakom, da so se udeležili svete maše, medtem ko so se preostali vojaki morali udeležiti nedenominacijske, monoteistične molitve. Še v 6 . stoletju pa je bila navzočnost vojaških duhovnikov v posameznih legijah bolj privilegij kakor pravilo (Jones 1953, 239-240). ${ }^{2}$

V zgodnjem obdobju se je tako vzpostavila primarna naloga duhovnikov, ko so sledili vojski na bojišče - da so upravičili pravi namen vojske s pridobitvijo božje podpore, posledica tega pa je bil tudi vpliv na moralo vojakov. Voj(šč)aki sami so morali dokazati, da so upravičeni do božje pomoči (med bitko) z zglednim izpolnjevanjem verskih dolžnosti (Bachrach 2011, 13).

Že v času Karla Vélikega, ki je začel združevati »vojskovanje s projekti pokrščevanja«, so škofje in duhovniki, ki so spremljali vojaške pohode, dobili nalogo, utemeljiti to delovanje, ko se krščanstvo ni več širilo s prepričanjem, ampak »prek prisile in svete vojne» (Moore 2018, 47).

Tako so med križarskimi vojnami duhovniki, ki so bili del križarskih vojska, imeli nalogo, da izvajajo dosledno in natančno pastoralno skrb. Prek pridiganja so morali vojake pozivati, naj se vedejo kot krščanski vojaki, pri tem pa so morali sami biti »zgled pravega krščanskega strahu pred Bogom in v ljubezni do Boga «. K vrnitvi na pravo, krščansko pot so morali pozvati tudi tiste, ki so se med spopadi (in v miru) izkazali za nemoralne (Bachrach 2004, 620).

2 O vlogi kristjanov v prvih treh stoletjih po Kr., glej Harnack, Militia Christi (1905). 


\section{Obsežna (ne le duhovna) oskrba}

Do konca prve polovice 20. stoletja, obdobja, ki sta ga na koncu zaznamovali dve svetovni vojni, so vojaški duhovniki imeli nalogo, izvajati duhovne obrede pred spopadi in po njih in zagotoviti vojakom izpolnjevanje religioznih oziroma verskih norm. Tako so krščanski vojaški duhovniki skrbeli za delitev svetih zakramentov, vojaški rabini in imami za blagoslovitev in ritualni zakol živine, vsi pa so imeli še dolžnost, skrbeti za ranjence in obolele (to je dostikrat presegalo samo duhovno oskrbo, saj so izvajali tudi osnovno medicinsko oziroma bolničarsko oskrbo) ter poiskati in zagotoviti primeren (verski) pokop padlih in mrtvih vojakov (ter tudi civilistov) (Allison 2016, 1-2; Biro 2014, 399-400).

Dalje so podpirali poveljniški, častniški kader pri njihovih odločitvah, ki so primarno zadevale moralo podrejenih vojakov, pa tudi družine padlih vojakov. $\mathrm{Na}$ administrativnem področju so bili vojaški duhovniki zadolženi za izdajo potrdil o smrti in pokopu ter občasno tudi porok. Kot visoko izobraženi ljudje so duhovniki $v$ avstro-ogrskih oboroženih silah sodelovati tudi pri cenzuri pisem, ki so jih vojaki pošiljali domov (Biro 2014, 399-400). Prav tako so vojaške duhovnike uporabili za širjenje propagande med vojaki, predvsem glede ohranjanje zvestobe avstro-ogrski monarhiji (Zaharia 2017, 293).

Že prej so številni vojaški duhovniki, ki so bili med redkimi ljudmi z znanjem pisanja, delovali tudi kot (ne)uradni kroniki: pisali so zgodovino vojaške enote oziroma ekspedicije (Dalton 2009).

\section{Apologeti in učitelji}

Med drugo svetovno vojno so vojaški duhovniki morali preseči svoje duhovne naloge tudi z apologetiko dejanj svoje lastne države in/ali oboroženih sil, to pa je značilno predvsem za totalitarne države (Allison 2016, 2).

Tako je v oboroženih silah tretjega rajha služilo tudi okoli tisoč katoliških in protestantskih vojaških duhovnikov; ubadali so se z dilemo služenja režimu, ki je preganjal krščanske Cerkve (Bergen 2001, 233-234). Georg Werthmann, ob koncu vojne v. d. katoliškega vojaškega škofa, je dejal: „Čutili smo, da smo bolj uporabni, če ostanemo zunaj koncentracijskega taborišča. Toda nikdar nismo ogrozili naših načel ali naših duš. Bili smo preganjani, vse odkar so nacisti prišli na oblast. In jaz vem osebno, da $v$ primeru nemške zmage $v$ tej vojni ne bi bilo več duhovščine $v$ Nemčiji.« (Faulkner 2010, 2)

Druga svetovna vojna velja tudi za prvo ideološko vojno, za spopad med dvema nasprotnima poloma (demokratični in totalitarni svet, verujoči proti nevernim); posledica tega je bila, da se je to preneslo tudi na versko raven (Allison 2016, 2). Tako so krščanski vojaški duhovniki v oboroženih silah tretjega rajha dostikrat v svoje pridige vpletali (verski) boj proti boljševizmu (komunizmu) z vidika obrambe vere, pri tem pa so uporabljali tudi križarske primerjave (Faulkner 2010, 11-12). Podobno retoriko so razvili tudi vojaški duhovniki v slovenskem domobranstvu (Kladnik 2017, 715). 
Po drugi svetovni vojni je svet doživel obširno sekularizacijo, kar se je pokazalo tudi pri duhovni oskrbi v številnih oboroženih silah. V nekaterih državah so tako v celoti ukinili duhovno oskrbo (države Varšavskega pakta), drugje so zmanjšali vlogo vojaških duhovnikov (npr. leta 1946 so v Združenem kraljestvu ukinili obvezno navzočnost pri svetih mašah vojaških duhovnikov), zato so vojaški duhovniki postali le »nekaj več kot poveličani socialni delavci« (McFarlane v Allison 2016, 2).

Kot posledica tega je $v$ modernem in postmodernem svetu postalo značilno, da vojaški duhovniki ne skrbijo le za duhovnost vojakov, ampak se ukvarjajo s celotno skrbjo za pripadnike oboroženih sil, ${ }^{3}$ pri tem pa uporabljajo svoje versko, pastoralno znanje za primerno svetovanje (Allison 2016, 2).

Pred koncem druge svetovne vojne je bilo delovanje vojaških kaplanov na splošno namenjeno večjim skupinam oziroma vojaškim enotam. Tako so bile celotne vojaške enote navzoče pri verskih obredih, od svetih maš do skupinskih odvez grehov. Največkrat je bila individualna obravnava vojakov namenjena le tistim, ki so bili ranjeni, so umirali ali dejansko že umrli. Tako se je v krščanskem obredju po 4. stoletju po Kr. izoblikovala tradicija večkratnih svetih spovedi (in ne le ene predsmrtne, življenjske spovedi), prav zaradi vojakov, ki so bili nenehno izpostavljeni smrti in zaradi svojega delovanja (možnost uboja/umora nasprotnika) izpostavljeni smrtnemu grehu (Bachrach 2011, 13-14).

\section{Medicinsko-psihološka skrb}

Medtem ko so pred 20. stoletjem vojaški duhovniki pomagali pri medicinski oskrbi ranjenih in obolelih vojakov, pa se je v drugi polovici 20. stoletja izkazalo, da lahko sodelujejo tudi pri psihološki oskrbi vojakov, še posebno tistih, ki so izpostavljeni travmatičnim dogodkom v miru in vojni (Adler in dr. 2018). ${ }^{4}$

Moss in Prince (2014, 151-2) to ponazorita: ॥Travmatizirani vojaki so tudi obremenjene duše, spopadajoč se s krizami vere in konflikti vesti. /.../ Ob določenih časih in mestih, vseeno, z vidika frontnih vojakov, delo pastoralne oskrbe preko kaplanov se ne razlikuje od prakse in ciljev vojaških voditeljev. Toda drugič, je pastoralna oskrba videna, kot da zagotavlja ločeno in vredno službo za vojake vseh činov v oboroženih silah."

$\checkmark$ raziskavi, ki so jo naredili Morgan, Hourani, Lane in Tueller (2016) v skupini 889 aktivnih vojakov kopenske vojske ZDA, se je izkazalo, da so pri vojakih, ki so iskali pomoč pri vojaških kaplanih v zadnjem letu, zabeležili 50,8 \% depresijo in $39,1 \%$ možnost posttravmatske stresne motnje, $26,6 \%$ jih je bilo pozitivnih na navzočnost generalizirane anksiozne motnje.

Pri tem se je izkazalo, da je religioznost pozitivno vplivala na preprečevanje sa-

Celostna skrb za pripadnike oboroženih sil v Slovenski vojski zajema zdravstveno, psihološko in socialnovarstveno oskrbo, pravno pomoč in svetovanje, religiozno duhovno oskrbo, športno dejavnost, organizirano preživljanje prostega časa in skrb za družinske člane (Šebalj 2010, 113-114).

4 O vlogi duhovnosti in religioznosti v stresnih situacijah, tudi v psihoterapiji, glej Košir 2020. 
momorilnosti vojakov in veteranov, ki so trpeli za posttravmatsko stresno motnjo ali doživeli moralno rano (Ames in dr. 2018, 6; Drescher in dr. 2018; Kopacz in dr. 2018). Vloga vojaških duhovnikov pri mentalni higieni vojakov se je pokazala v postmodernih mednarodnih operacijah, saj so duhovniki znali identificirati, preprečevati in svetovali glede duševnih motenj, od lažje čustvene napetosti do poskusa samomora (Besterman-Dahan in dr. 2012). Tako so vojaški duhovniki postali "partnerji v operativni psihologiji «, s tem pa razbremenijo vojaške psihologe, saj so navadno bolj navzoči med vojaki kakor psihologi (Frederich in dr. 2011, 168).

Vse večjo vlogo imajo vojaški duhovniki tudi pri preprečevanju in zdravljenju zasvojenosti med pripadniki oboroženih sil, in to prek pastoralne oskrbe (Robertson 2016).

\section{Povezovalci}

Ob vse večjem številu mednarodnih (mirovnih) operacij po drugi svetovni vojni so vojaški duhovniki, ki so bili del kontingentov v tujini delujočih oboroženih sil, postali tudi pomemben del teh misij. Sodelovali so na sestankih z verskimi voditelji in tako vzpostavili stik z voditelji lokalnega okolja, to pa jim je omogočili dodatno delovanje med lokalnim prebivalstvom, še posebno med humanitarnimi misijami. Vojaški duhovniki tako zmorejo zapolnitvi ,informacijsko vrzel', ki nastane zaradi nerazumevanja različnih kultur in religij. To nerazumevanje jezika, simbolizma, zgodovine in arheologije lahko privede do zaostritve odnosov med tujim kontingentom in lokalnim prebivalstvom, preprečijo pa jo lahko prav vojaški duhovniki, seveda v nesekulariziranem okolju (Lee, Burke in Crayne 2005, 3-18).

Tako so leta 2001 v vojni mornarici ZDA razvili program, po katerem so vojaški kaplani postali orodje preprečevanja konfliktov na mednarodnih misijah, in to z vzpostavitvijo odkritih stikov z lokalnimi verskimi voditelji in s svetovanjem vojaškim poveljnikom glede verskih in kulturnih posledic morebitne poveljniške odločitve (Johnston 2009, 25). Vojaški duhovniki so prevzeli »mirovniško vlogo med verskimi voditelji in njihovimi skupnostmi ", pri tem pa si prizadevajo za »miroljubne odnose med razklanimi skupnostmi z zagotavljanjem priložnosti za izvedbo srečanj - z vzpostavitvijo varnega in preobrazbenega prostora za dialog " (Moore 2014, 95-96).

Na mirovnih ali humanitarnih misijah so vojaške organizacije dostikrat, če ne večinoma prisiljene sodelovati z nevojaškimi subjekti, $h$ katerim sodijo tudi različne nevladne, civilne organizacije. Vojaški kaplani, sami povezovalci med vojaškim in civilnim okoljem, tako primarno sodelujejo z organizacijami, ki delujejo na področju humanitarnosti, človekovih pravic, civilne družbe (vključno z vpeljavo demokracije) in razrešitve konfliktov (McLaughlin 2002, 21).

Medverski dialog ni pomemben samo med delovanjem $v$ tujini, ampak tudi znotraj same vojaške organizacije, $v$ kateri so navzoči vojaki različnih veroizpovedi. Vojaško duhovništvo tako deluje na istem principu kakor širša (civilna) družba, 
z integracijo različnih (verskih) oziroma družbenih skupin v eno družbo, pri tem pa se zagotavljajo verske potrebe posameznikov oziroma skupin (Peterson 2015, 4-5). To v nekaterih oboroženih silah dosegajo tudi s tem, da vojaški duhovnik »usposablja vojaško osebje, da spoštuje verska prepričanja, promovira mir in harmonijo« (Seiple 2009, 45). V preteklosti, predvsem v multietničnih državah, je bilo za vojaške duhovnike pomembno, da so poznali več jezikov, tako so namreč lahko duhovno skrbeli za pripadnike več nacij, ki so služili v istih oboroženih silah (Šimac 2020b, 171).

V zadnjem času nekatere države uvajajo tudi ateistične oziroma humanistične vojaške duhovnike, ki naj bi skrbeli oziroma skrbijo za ateistične pripadnike oboroženih sil (Kolenc 2014, 395).

\section{Branitelji reda in prava}

Vojaški duhovniki zaradi vloge, ki jo imajo znotraj oboroženih sil, in predvsem zaradi ugleda, ki ga uživajo med vojaškim osebjem, lahko preprečujejo tudi negativnost oziroma toksičnost vojaških voditeljev. Tako lahko nadrejene opozorijo na potrebe in zadržke podrejenih, ne da bi nadrejeni vedeli, kdo od podrejenih je to izrazil, in vzpostavijo dialog v organizaciji, ki velikokrat tega ne omogoča. To se dogaja predvsem zato, ker duhovnike vojaško vodstvo posluša, duhovniki poznajo organizacijsko kulturo oboroženih sil in osebnosti vpletenih oseb. S tem nastane možnost za mediacijo oziroma rešitev problema na najbolj nekonflikten način, ne glede na čin vpletenih (Messinger 2013, 123).

Benham Rennick $(2011,93)$ pravi, da vojaški kaplani, ki imajo simbolični ,nevtralni' čin, delujejo prek ,duhovništva prisotnosti‘ (ministry of presence), ko lahko posredujejo zunaj poveljniške linije in upoštevajo neujemanja med institucionalnimi cilji in človeškimi potrebami.

V nekaterih situacijah lahko vojaški duhovniki prek svoje pastoralne skrbi pridejo tudi do informacij glede vojnih zločinov, storjenih znotraj njihove lastne vojaške organizacije. Med vietnamsko vojno leta 1968 je enota ameriških vojakov pobila prebivalce vasi My Lay. Ta vojni zločin je videl pilot helikopterja, o tem je povedal je še isti dan vojaškemu kaplanu, ki je o tem poročal svojemu nadrejenemu (Olson in Roberts 1998, 117-119).

Kakor že rečeno, vojaški duhovniki naj bi si prizadevali tudi za ponovno vzpostavitev moralnosti med vojaki; to se v sedanjosti kaže med vojaškimi zaporniki, duhovna oskrba pa ima funkcijo v rehabilitaciji tega zapornika (Brink 1953, 36).

\section{Tudi za vojaške družine in veterane}

Po drugi svetovni vojni, ko so se vzpostavile večje, stalne oborožene sile, ki so bile v posameznih državah garnizirane v vojaških bazah, kjer so pripadniki oboroženih 
sil živeli s svojimi družinami (kakor tudi v državah, kjer profesionalni vojaki živijo zunaj vojašnic), se je hkrati pokazala potreba po duhovni oskrbi za člane družin vojakov, vpetih v vojaško okolje in vojaški način življenja. Poleg individualne pastoralne oskrbe, ki je podobna, če ne identična s ,civilno' pastoralno oskrbo, vojaški duhovniki izvajajo tudi zakonsko-družinsko svetovanje, še posebno zaradi specifik vojaškega življenja, kakor so dolgotrajna odsotnost, travmatične izkušnje, možnost hude poškodbe ali smrti itd. (Moon 2016, 128-134).

Sipe $(1993,25-43)$ izpostavlja, da imajo vojaški duhovniki možnost, biti vpleteni v vse ravni človeškega življenja od rojstva do smrti. Poleg običajnih življenjskih stresnih okoliščin morajo pri tem upoštevati še geografske preselitve, razbite odnose, dnevne vožnje ...

Vojaški duhovniki imajo tudi pomembno vlogo pri zagotavljanju duhovne oskrbe umirajočim veteranom, ki jim lahko pomagajo »razrešiti stres, povzročen zaradi z bojem povezanih dogodkov, ki so v konfliktu z njihovimi osebnimi prepričanji« (Chang, Stein in Skarf 2015, 635).

\section{Glasniki miru}

Moss in Prince $(2014,152-153)$ sta naloge vojaških duhovnikov razdelila na tri skupine: 1) naloge, povezane z religioznostjo, 2) naloge, povezane z vojaško organizacijo, in 3) naloge, povezane s svetovanjem in oskrbovanjem posameznih vojakov in morebiti njihovih družin. V prvo skupino sodijo verske norme, običaji in obredi, ki se izvajajo ob različnih časih in n različnih krajih, pri tem pa vojaški duhovniki skrbijo tudi za verske potrebe drugače verujočih (omogočanje stika vojakov z njihovimi (civilnimi) verskimi delavci). Naloge, povezane z vojaško organizacijo, so predvsem: vzdrževanje vrednot oboroženih sil, promocija samodiscipline, svetovanje poveljujočim glede kadrovskih zadev, sodelovanje z vojaško-medicinskim osebjem, poučevanje (npr. glede spolnosti) in vzdrževanje morale vojakov. V tretjo skupino sodijo svetovanje in pomoč ranjenim in bolnim, zagotavljanje prve pomoči, skrb za padle in umrle pripadnike, obveščanje družin pripadnikov, svetovanje veteranom in tudi njihovim družinam.

Moore (2008, po Volfu 2009) ima zgoraj navedene tri skupine nalog vojaških duhovnikov za njihovo osrednjo, splošno nalogo, a v zadnjem času se vse bolj izpostavlja vloga vojaških duhovnikov kot ,agentov miru'. Vojaški duhovniki morajo upoštevati načelo pravične vojne in ohranjanje miru v globaliziranem svetu, v katerem so različne religije »ena izmed najbolj mogočnih sil v svetu danes«. (Vojaška) sila je namreč sama nezmožna uveljaviti mir v svetu, v katerem so upoštevane človekove pravice in uveljavljeni demokratični ideali. To se lahko zgodi z uporabo religije, ki »igra vlogo pri definiranju ljudskih identitet skupnosti«. Vojaški duhovniki imajo pri tem nalogo, da iščejo načine pomiritve in združitve nasprotujočih si družbenih skupin, prav v moči religije (Volf 2009, 33-35). 


\section{Namesto sklepa}

Iz naštetih zgledov lahko razvidimo, da je duhovna oskrba v oboroženih silah vse od začetkov do današnjih dni sklenila nekakšen krog: od prvotne skupinske, množične oskrbe celotne vojaške enote je prišla do individualne obravnave posameznih vojakov. Hkrati vojaški duhovniki ne izvajajo samo duhovne, pastoralne oskrbe, ampak zagotavljajo tudi pomoč na drugih področjih (npr. na zdravstvenem, psihološkem itd.), to pa presega njihovo temeljno zadolžitev.

Kot del vojaške in verske organizacije vojaški duhovniki presegajo in povezujejo obe organizaciji in so tako simbolično hkrati posvetni in svetni. Njihovo delo se ne navezuje le na pripadnike oboroženih sil, ampak $v$ zadnjih desetletjih $v$ njihov delokrog sodijo tudi družinski člani, (vojni) begunci, nevladne organizacije itd. V današnjem svetu, $v$ katerem vse bolj vladajo versko in nacionalno motivirani konflikti, imajo lahko prav vojaški duhovniki na podlagi poznavanja različnih kultur in religij odločilno vlogo pri zagotavljanju in ohranjanju miru na konfliktnih območjih.

Zato je treba pri usposabljanju bodočih (vojaških) duhovnikov zagotoviti, da prejmejo čim bolj širok nabor znanja, ki presega teološko-religiološke okvire in vključuje - ni omejeno s tem - kulturologijo, medicino, psihologijo, zakonsko-družinsko terapijo itd. Tako lahko vojaški duhovniki znotraj oboroženih sil delujejo v luči miru, kot glasniki sprave in povezovalci narodov.

Kljub vsem dodatnim vlogam in dolžnostim, ki so jih v zadnjih desetletjih začeli opravljati, pa vojaški duhovniki še vedno ostajajo "avtentične priče pravega upanja, rojenega iz obljube Njega, ki je prava ljubezen«; tako v vojnih razmerah prinašajo upanje vojakom - na (večno) življenje (Zelinskyy 2016).

\section{Reference}

Adler, Abby, Sadia Chadhury, Barbara Stanley, Marjan Ghahramanlou-Holloway, Ashley Bush in Gregory K. Brown. 2018. A Qualitative Analysis of Strategies for Managing Suicide-Related Events during Deployment from the Perspective of Army Behavioral Health Providers, Chaplains, And Leaders. Military Psychology 30, št. 2:87-97. https://doi.org/10.1080/08995605.2017.1420979.

Allison, Neil E. 2016. A Free Church Perspective on Military Chaplains Role in Its Historical Context. In die Skriflig 50 št. 1:1-8. https://doi. org/10.4102/ids.v50i1.2163.

Ames, Donna, Zachary Erickson, Nagy A Youssef, Irina Arnold, Chaplain Sam Adamson, Alexander C Sones, Justin Yin, Kerry Haynes, Fred Volk, Ellen J Teng, John P Oliver in Harold G Koenig. 2019. Moral Injury, Religiosity, and Suicide Risk in U.S. Veterans and Active Duty Military with PTSD Symptoms. Military Medicine 184, št. 3/4:271-178. https://doi. org/10.1093/milmed/usy148/5038451.
Bachrach, David Steward. 2004. The Friars Go to War: Mendicant Military Chaplains, 1216-c. 1300. The Catholic Historical Review 90, št. 4:617-633.

Bachrach, David. 2011. Military Chaplains and the Religion of War in Ottonian Germany, 9191024. Religion, State and Society 39, št. 1:3-31.

Benham Rennick, Joanne. 2011. Canadian Military Chaplains: Bridging the Gap Between Alienation and Operational Effectiveness in a Pluralistic and Multicultural Context. Religion, State and Society 39, št. 1:93-109. https://doi.org/10 .1080/09637494.2011.546507.

Bergen, Doris L. 2001. German Military Chaplains in World War II and the Dilemmas of Legitimacy. Church History 70, št. 2:232-247.

Besterman-Dahan, Karen, Susanne W. Gibbons, Scott D. Barnett in Edward J. Hickling. 2012. The Role of Military Chaplains in Mental Health Care of the Deployed Service Member. Military Medicine 177, št. 9:1018-1033. 
Biro, Akos. 2014. Jewish Military Chaplains in the Austro-Hungarian Armed Forces during World War I. Acta Ethnographica Hungarica 59, št. 2:397-406.

Brink, Frederick W. 1953. The Role of the Chaplain in the Rehabilitation of Military Prisoners. Pastoral Psychology 4:36-42.

Čepar, Drago. 2000. Duhovna oskrba vojakov v Evropi in Natu. Vojstvo 7:85-104.

- - - 2010. Duhovna oskrba vojakov v Evropi in Natu ter področni sporazum s Svetim sedežem. Bilten Slovenske vojske 12, št. 4:149-165.

Chang, Bei-hung, Nathan R. Stein in Lara M. Skarf. 2015. Spiritual Distress of Military Veterans at the End of Life. Palliative and Supportive Care 13, št. 3:635-639. https://doi. org/10.1017/S1478951514000273.

Dalton, Charles. 2009. Army Chaplains as Military Historians and Diarists, 1688-1712. Royal United Services Institution: Journal 41, št. 236:1287-1291.

Drescher, Kent D., Joseph M. Currier, Jason A. Nieuwsma, Wesley McCormick, Timothy D. Carroll, Brook M. Sims in Christine Cauterucio. 2018. A Qualitative Examination of VA Chaplains' Understandings and Interventions Related to Moral Injury in Military Veterans. Journal of Religion and Health 57:2444-2460. https://doi.org/10.1007/s10943-018-0682-3.

Faulkner, Lauren N. 2009. Against Bolshevism: Georg Werthmann and the Role of Ideology in the Catholic Military Chaplaincy, 1939-1945. Contemporary European History 19, št. 1:1-16.

Fischer-Bovet, Christelle. 2014. Army and Society in Ptolemaic Egypt. Cambridge: Cambridge University Press.

Frederich, Peter. 2011. The Role of Chaplains in the Operational Army. V: Elspeth Cameron Ritchie, ur. Combat and Operational Behavioural Health, 163-170. Falls Church, VA; Fort Detrick, MD: Office of The Surgeon General, United States Army; Borden Institute.

Harnack, Adolf. 1905. Militia Christi: Die christliche Religion und der Soldatenstand in den ersten drei Jahrhunderten. Tübingen: J. C. B. Mohr Verlag.

Johnston, Douglas M. 2009. U.S. Military Chaplains: Redirecting a Critical Asset. The Review of Faith \& International Affairs 7, št. 4:25-32. https://doi. org/10.1080/15570274.2009.9523412.

Jones, A. H. M. 1953. Military Chaplains in the Roman Army. Harvard Theological Review 46, št. 4:239-240.

Kladnik, Tomaž. 2017. Bodi tudi v vojski kristjan: duhovna oskrba v Slovenskem domobranstvu. Bogoslovni vestnik 77, št. 3-4:705-716.

Kolenc, Antony Barone. 2014. Not ,For God and
Country': Atheist Military Chaplains and the Free Exercise Clause. University of San Francisco Law Review 48:395-456.

Kopacz, Marek S., Laurie M. O'Reilly, Chris C. Van Inwagen, Theodore L. Bleck-Doran, William D. Smith in Nancy Cornellb. 2014. Understanding the Role of Chaplains in Veteran Suicide Prevention Efforts: A Discussion Paper. SAGE Open, oktober: 1-10. https://doi. org/10.1177/2158244014553589.

Košir, Meta. 2020. Duhovnost in religioznost v stresnih situacijah in mesto duhovnosti v psihoterapiji. Bogoslovni vestnik 80, št. 4:915925. https://doi.org/ 10.34291/BV2020/04/ Kosir

Lee, William Sean, Christopher J. Burke in Zonna M. Crayne. 2005. Military Chaplains as Peace Builders: Embracing Indigenous Religions in Stability Operations. Maxwell Air Force Base, Alabama: Air University Press.

Liuski, Tiia, in Martin Ubani. 2020. How is Military Chaplaincy in Europe Portrayed in European Scientific Journal Articles between 2000 and 2019? A Multidisciplinary Review. Religions 11, št. 540:2. https://doi.org/10.3390/ rel11100540.

Lunze, Stefan. 2004. Serving God and Caesar: Religious personnel and their protection in armed conflict. International Review of the Red Cross 86, št. 853:69-92. https://doi. org/10.1017/S1560775500180101.

McLaughlin, Paul. 2002. The Chaplain's Evolving Role in Peace and Humanitarian Relief Operations. Washington DC: United States Institute of Peace.

Mesarič, Violeta Vladimira. 2012. Duhovna oskrba med vojaki. Stati inu obstati 15/16:295-301.

Moon, Zachary. 2016. Pastoral Care and Counseling with Military Families. Journal of Pastoral Care \& Counseling 70, št. 2:128-135. https:// doi.org/10.1177/1542305016633663.

Moore, Michael Edward. 2018. The Frankish Church and Missionary War in Central Europe. V: Radoslaw Kotecki, Jacek Maciejewski in John S. Ott, ur. Between Sword and Prayer: Warfare and Medieval Clergy in Cultural Perspective, 46-87. Leiden; Boston: Brill.

Moore, S. K. 2008. Military Chaplains as Agents of Peace: The Theology and Praxis of Reconciliation in Stability Operations Base on the Writings of Miroslav Volf and Vern Neufeld Redekop. Doctoral Dissertation. Saint Paul University, Ottawa, Canada.

- - - 2014. Military Chaplains as Whole-of-Government Partners. V: Eric Patterson, ur. Military Chaplains in Afghanistan, Iraq, and Beyond: Advisement and Leader Engagement in 
Highly Religious Environment, 95-112. Lanham, MD: Rowman \& Littlefield.

Morgan, Jessica Kelley, Laurel Hourani, Marian E. Lane in Stephen Tueller. 2016. Help-Seeking Behaviors Among Active-Duty Military Personnel: Utilization of Chaplains and Other Mental Health Service Providers. Journal of Health Care Chaplaincy 22, št. 3:1-16. https://doi.org/ 10.1080/08854726.2016.1171598.

Naiden, F. S. 2019. Soldier, Priest, and God: A Life of Alexander the Great. Oxford: Oxford University Press.

Olson, James S., in Randy Roberts. 1998. My Lai: A Brief History with Documents. Boston, MA: Palgrave Macmillan.

Peterson, Michael T. 2015. The Reinvention of the Canadian Armed Forces Chaplaincy and the Limits of Religious Pluralism. Master Thesis. Wilfrid Laurier University, Waterloo, Canada.

Plut, Jože. 2001. Duhovna oskrba vojaških oseb: analiza slovenskih povojnih razmer, pastoralni modeli in predlogi. Doktorska naloga. Teološka fakulteta, Univerza v Ljubljani.

- - - 2002. Za pravice človeka: predstavitev doktorskega dela z naslovom Duhovna oskrba vojaških oseb, analiza slovenskih povojnih razmer, pastoralni modeli in predlogi. Ljubljana: Družina.

Plut, Jože, in Violeta Vladimira Mesarič. 2003. (Religiozna) duhovna oskrba. Bilten Slovenske vojske 5, št. 1:133-143.

Plut, Jože, Violeta Vladimira Mesarič in Silvestra Sadar, ur. 2010. Vojaški vikariat: 10 let delovanja. Ljubljana: Ministrstvo za obrambo Republike Slovenije.

Pregelj, Milan. 2017. Duhovna oskrba na misijah. V: Vasilije Maraš, ur. 20 let v službi miru: 20 let sodelovanja Republike Slovenije v mednarodnih operacijah in na misijah: zbornik, 432-437. Ljubljana: Ministrstvo za obrambo Republike Slovenije.

Pregelj, Milan, Jože Plut in Tamino Petelinšek, ur. 2005. Zvest Bogu in domovini = Deo et patriae fidelis: zbornik ob 5. obletnici Vojaškega vikariata. Ljubljana: MORS, GŠSV - Vojaški vikariat.

Ratej, Mateja. 2014. Januš Golec - vojaški kurat 97. avstrijskega pešpolka na vzhodni fronti v letih 1914-1916. V: Grdina, Igor, Alja Brglez in Jonatan Vinkler, ur. Velika vojna in mali ljudje: zbornik razprav, 21-27. Ljubljana: Inštitut za civilizacijo in kulturo - ICK.

Robertson, Heather C. Spirituality, Substance Use, and the Military. Vistas Online. https://www. counseling.org/docs/default-source/vistas/ spirituality-substance-use-and-the-military. pdf?sfvrsn=821d4a2c_4 (pridobljeno 20.11. 2020).

Schwartzwald, Jack L. 2014. The ancient Near East, Greece and Rome: A Brief History. Jefferson, NC: McFarland \& Company.

Seiple, Chris. 2009. Ready ... or not?: Equipping the U.S. Military Chaplain for Inter-religious Liasion. The Review of Faith \& International Affairs 7, št. 4:43-49.

Sipe, Richard V. 1993 The Use of Ritual in the Pastoral Care and Support of Families. Master's Thesis. Duke University, Durham, NC.

Šebalj, Drago. 2010. Celostna skrb za pripadnike Slovenske vojske v mednarodnih operacijah in na misijah. Bilten Slovenske vojske 12, št. 4:111-129.

Šimac, Miha. 2013. Vojaški kurati iz osrednjih slovenskih dežel v avstro-ogrskih oboroženih silah v prvi svetovni vojni. Doktorska disertacija. Teološka fakulteta, Univerza v Ljubljani.

---. 2014. Vojaški duhovniki iz slovenskih dežel pod habsburškim žezlom. Ljubljana: Teološka fakulteta.

- - - 2020a. Janez (Ivan) Andolšek (1885-1917): vojaški kurat. V: Ludvik Mihelič, ur. Sodraških 800: monografija ob 800-letnici prve pisne omembe Sodražice, 807-814. Sodražica: Občina Sodražica.

- - - 2020b. Croatian Military Chaplains Marko Hummel and Ivan Kralj in the Light of the Archival Records of the War Archives in Vienna. Diacovenisa 28, št. 2:167-187.

Volf, Miroslav. 2009. Agents of Peace in Theaters of War: Rethinking the Role of Military Chaplains. The Review of Faith \& International Affairs 7, št. 4:33-41.

Zaharia, Ionela. 2017. For God and/or Emperor: Habsburg Romanian Military Chaplains and Wartime Propaganda in Camps for Returning POWs. European Review of History: Revue européenne d'historie 24, št. 2:288-304.

Zelinskyy, Andriy. 2016. A Ukrainian Military Chaplain's Candid Reflections on Christmas. Euromaidenpress, 6. 1. http://euromaidanpress.

com/2016/01/06/a-ukrainian-military-chaplains-candid-reflections-on-christmas/ (pridobljeno 11. 12. 2020). 